\section{Special cases - practical psychoanalytic work in untypical fields}

\author{
Mag. Waltraud Schönhart, MSc, MBA, BA.pth \\ Doctoral student of psychotherapy science SFU Vienna, Head of the Therapy Departement Haus der \\ Barmherzigkeit Vienna / Tokiostraße 4, 1220 Wien \\ E-Mail: waltraud.schoenhart@hausderbarmherzigkeit.at
}

Tel.: +43-1-90181-3169 Fax: +43-1-90181-3308

\section{Resilience in Psychotherapy}

„Resilience is accepting your new reality, even if it's less good than the one you had before. You can fight it, you can do nothing but scream about what you've lost, or you can accept that and try to put together something that's good." Elizabeth Edwards, a name that is tied to the concept of resilience. Factors connected to a person's resilience are: reality orientation, confidence in one's own abilities, communication and the ability to regulate one's own impulses and feelings.

As a psychoanalyst, I am struck how similar these factors are to the process, developments and goals of psychoanalytic treatment. Let us take a look at the goals of psychoanalytic treatment:

1. Reality orientation: one of Freud's main quotes is "Where Id is, there shall be Ego". A translation of this quote for the lay would mean: where life is filled with fantasies and illusions - this area should be replaced by an orientation to reality. This is often a painful process since dreams are a substitute for painful reality.

2. Confidence in one's own abilities: ambiguities, which are central to the erosion of confidence are a central issue in psychoanalysis. The defeating forces at work here are constantly an object of our work.

3. Communication: there is nothing that is not communication in psychoanalysis. The patients entrance into a room is already a statement! In psychoanalysis we constantly try to understand the scene which the patient is trying to show us or themselves.

4. Regulation of feelings: Becoming the subject and not the object is one of the goals of psychoanalysis.

The phoenix is a symbol for resilience. A bird rising from the ashes, reborn to rise to a new life. A trauma depicted by a fire had destroyed one life which, now comes back to life. This motif lives with us as form of our mythology. This myth lives with us in a broad width of meanings. The range of the meanings of the phoenix in our lives goes from the pathological to the benign. Pathological would be the fantasy or general assumption of rebirth or resurrection with 72 virgins and at the more healthy end of the spectrum would be a wish or fantasy of just being able to sit in a wheelchair and have a normal conversation with beloved ones again. 
Belonging to the features of resilience is the desire to resist the pull to the end of all and the resulting decay. In this thought we can recognize Freud's dichotomy of the life and death drives which are with us until our own death.

Resilience may be the fight against Thanatos, Freud's deathdrive. As individuals and members of a species in development we all face death and thus decompose. Libido - the drive of love is the unifying force in us connecting to parts to ever larger wholes.

Psychotherapy, especially psychoanalysis, which incorporates the life and death drive, is a method to examine these dynamics in us. It is also a method to enhance and develop the main factors contributing to the development of resilience.

The purpose of the following case presentation is to illustrate consequences of the choice: Either Thanatos or Libido!

\section{Case Presentation}

The following case was considered in more ways than one as 'hopeless'. Regular psychotherapy was questionable and to think of this patient as a psychoanalytic patient was beyond imagination. Even though the conditions for beginning a therapy were difficult, if they were there at all, the therapy turned out to be a success.

The patient Univ. Prof. Dipl. Ing. DDr. S., who is now 81 years of age was admitted with a subarachnoid hemorrhage at the age of 77 to a Viennese geriatric hospital in which I work. His prognosis was negative if not hopeless in all aspects - he was somnolent, could neither speak, swallow, control his bowels, connected to a PEG-tube as well as a suprapubic cathetus. The most his daughter and companion B., a Viennese psychoanalyst, expected was to sit with $\mathrm{S}$ in a modern wheelchair under a tree, holding his hand and to have simple conversations. However, it all changed and took a different development.

After $1 \frac{1}{2}$ years in our care hospital, after many different therapies in which I was involved $\mathrm{S}$ was released to a rehab and then released home, still having an organic brain syndrome, however having complete control over his speech and language functions, his thinking processes were still slow, without a PEG-tube, continent, being able to walk a few steps.

Six months after his release from the rehab, in the mean time I had no contact with S. I received unexpectedly a call from B., asking if I could continue the talks I had with him. She stated that the conversations I had with him had helped a lot, mostly he had become much more sociable and loving...

The call delighted me, I accepted the offer, and felt honoured and was curious to hear from S. He called and the therapy could start.

S.'s initial objectives were to help him regain his memory of the time before his massive trauma which had torn him out of a very successful life. In the course of the therapy this initial objective continued to widen to an understanding of his self, his relations and the dynamics of his conflicts. The symbolic equation of the first phase after his subarachnoid hemorrhage with a regression in the autistic-contiguous position, following the paranoid-schizoid and the depressive position as well as the regaining of control over his oral, anal and genital functions made it possible to connect his life history with his here and now and to think about options of his future. The focus of the topics included the relationship to his parents; the cold hearted mother; the loving, creative weak father; his unresolved oedipal conflict; his relationship to his children; his relationships to women and his sexual life. It was especially exciting to also follow the neuroscientific aspects. Early defense mechanisms such as denial of reality, omnipotence and idealisation, which were also caused by his 
brain damage, changed within the course of therapy to more mature ones as intellectualisation. Freud's statement "Where Id was, Ego should be" (Freud, [1933] 2000 , S. 516) applies to the process of S.'s therapy Ego-functions were strengthen so that he could deal with reality, the results of his trauma and ageing much better.

For the past $2 \frac{1}{2}$ years S. was treated by myself in a psychoanalytic treatment twice weekly in his Viennese apartment. Especially challenging in the work with S. was the intellectual challenge: S. is a scientist and philosopher, his resistances, his defences, his transferences and my countertransferences, as well as the abstinence, which is defined by an inner attitude take on new contures. This case is a prime example of how psychotherapy is a process resembling resilience: overcoming extreme difficulties and regaining a new and hopefully better life.

\section{References and Notes}

1. Auchter, T., \& Strauss, L. V. (2003). Kleines Wörterbuch der Psychoanalyse. Göttingen: Vandenhoeck \& Ruprecht.

2. Ermann, M. (2007). Psychosomatische Medizin und Psychotherapie. Stuttgart: Kohlhammer.

3. Freud, S. ([1914] 2000). Studienausgabe Schriften zur Behandlungstechnik (Vol. Ergänzungsband). Frankfurt am Main: S. Fischer.

4. Freud, S. ([1914] 2000). Zur Einführung des Narzißmus. In Studienausgabe Psychologie des Unbewußten (pp. 37-68). Frankfurt am Main: S. Fischer.

5. Freud, S. ([1933] 2000 ). XXXI. Vorlesung: Die Zerlegung der psychischen Persönlichkeit. In Studienausgabe Vorlesung zur Einführung in die Psychoanalyse Und Neue Folge (Vol. 1, pp. 496516). Frankfurt am Main: S. Fischer.

6. Kaplan-Solms, K., \& Solms, M. (2007). Neuropsychoanalyse. Stuttgart: Klett Cotta.

7. Loch, W. (1989). Die Krankheitslehre der Psychoanalyse. Stuttgart: S. Hirzel.

8. Möller, H.-J., Laux, G., \& Deister, A. (2009). Psychiatrie und Psychotherapie. Stuttgart: Thieme.

9. Willi, J. (1975). Die Zweierbeziehung. Reinbek: Rowohlt

(C) 2015 by the authors; licensee MDPI and ISIS. This abstract is distributed under the terms and conditions of the Creative Commons Attribution license. 